Nama $\quad$ Hasniar

Nim $\quad: 90100118042$

Kelas $\quad$ : Ekonomi islam

\title{
KONSEP EKONOMI PADA MASA
}

( Abu Bakar, Umar Bin Khattab, Utsman Bin Affan, Dan Ali Bin Abi Thalib)

1) Pada Masa Abu Bakar

Masa kepemerintahan abu bakar yakni berlangsung selama 2 tahun dan pada masa pemerintahannya abu bakar berfokus pada persoalan dalam negeri. Adapun permasalahan-permasalahan yang harus dihadapi yakni abu bakar harus berhadapan dengan kelompok murtad, pembangkang zakat dan nabi palsu. Yang berakhir dengan pengambilan keputusan untuk berperan tersebut yakni dikenal dengan sebutan perang riddah ( perang melawan kemurtakan)

Adapun kebijakan ekonomi yakni abu bakar menerapkan praktek akad-akad perdagangan yang sesuai dengan prinsip syariah. Selama masa kepemimpinanya ia menerapkan beberapa kebijakan umum diantaranya yakni menegakkan hukum dengan cara memerangi kaum yang tidak mau membayar zakat.

Pada masa pemerintahan abu bakar belum banyak perubahan atau inovasi yang baru yang berkaitan dengan sektor ekonomi dan keuangan negara. kondisinya masih seperti pada masa rasulullah, kondisi ini dibentuk oleh konsentrasi abu bakar dalam memerangi kaum yang enggan membayar zakat.

Hasil pengumpulan zakat dijadikan sebagai pendapatan negara dan disimpan dalam baitul mal untuk kemudian didistribusikan kepada kaum muslimin tanpa tersisa sehingga pada masa abu bakar harta baitu mal tidak pernah menupuk dalam waktu yang lama. Abu bakar juga menerapkan prinsip kesamarataan yakni memberikan jumlah yang sama kepada para sahabat dan tidak membedabedakannya ${ }^{1} \mathrm{Al}$ - gazali menyarankan agar dalam memanfaatkan pendapatan negara, negara bersifat fleksibel yang berlandaskan pada kesejahteraan umat ${ }^{2}$

\footnotetext{
${ }^{1}$ Lailatul qadriyah "buku ajar sejarah pemikiran ekonomi islam” 2018, hlm 21-22.

${ }^{2}$ Sirajjudin,“ konsep pemikiran al-ghazali ”jurnal laa maisyir vol 3 no 1 juni 2016, hal 57
} 
2) Pada Masa Umar

pemerintahan umar berlangsung selama sepuluh tahun, banyak kebijakankebijakan yang dilakukan pada masa umar, termasuk dalam bidang perekonomian pemerintahan yakni perluasan praktik ekonomi islam yang semakin luas dan maju dibandingkan pada masa abu bakar di buktikan dengan di taklukannya negara-negara yang ada di sekitar jazirah arab termasuk daerah persia dan romawi ( syiria, palestina dan mesir) atas keberhasilan tersebut umar dijuluki sebagai the saint paul of islam

dalam pemerintahannya ada beberapa kebijakan umar terkait perekonomian pada masa itu yakni pendirian lembaga baitul mal, pajak pengelolaan tanah ( kharaj) dan zakat

3) Pada Masa Utsman

Pada enam tahun pertama kepemimpinanya banyak negara yang telah dikuasainya yakni Balkan, jabul ,grozni, kerman dan sistan. Setelah negara-negara tersebut ditaklukan, pemerintahan khalifah utsman menata kembali dan mengembangkan sistem yang telah diberlakukan oleh umar. Utsman kemudian mengadakan kontrak perdagangan dengan negara yang telah ditaklukannya dalam rangka mengembangkan potensi sumber daya alam,

Adapun perbedaan antara kebijakan fiskal utsman dengan sebelumnya yakni usman tidak mengambil upah dari kantornya melainkan ia meringankan beban pemerintah dalam hal serius bahkan menyimpan uangnya pada bendahara negara. Kebijakan yang dilakukan utsman juga berbeda dengan kebijakan sebelumnya yaitu ia tidak memiliki kontrol harga. Pada masa kepemerintahannya juga berbagai kebijakan utsman banyak menguntungkan keluargannya sehingga menimbulkan kekecewaan diantara kaum muslimin sehingga berimbas pada kekacauan politik dan berakhir dengan terbunuhnya sang khalifah

4) Pada Masa Ali Bin Abi Thalib

Adapun kebijakan ekonomi pada masa pemerintahan Ali yakni menetapkan pajak terhadap pemilik hutan sebesar 4000 dirham dan mengizinkan ibnu Abbas, gubernur kufah untuk memungut zakat terhadap sayuran segar yang digunakan sebagai bumbu 
masakan. Pada masa pemerintahannya juga Ali memiliki prinsip bahwa pemerataan distribusi uang rakyat yang sesuai dengan kapasitasnya.$^{3}$

\section{DAFTAR PUSTAKA}

Dan Ekonomi Pada Masa Nabi Muhammad. Bab II Ekonomi Pada Masa Nabi Muhammad Dan Khulafaur Rasyidin, Buku Ajar Sejarah Pemikiran Ekonomi Islam, 2018, 73:16

Sirajjudin, (2016) “ konsep pemikiran al-ghazali ”jurnal laa maisyir 3 (1 )

Mudhiiah, K. (2016) “Analisis sejarah pemikiran ekonomi islam masa klasik “ IQTISHADIA, 8 (2)

\footnotetext{
${ }^{3}$ Kharidatul Mudhiiah, "Analisis sejarah pemikiran ekonomi islam masa klasik"
} IQTISHADIA, Vol 8 No 2 2016, hal 199-207. 